\title{
The determination of the influence degree of mining-geological and mining-technical factors on the safety of the degassing system
}

\author{
Ruslan Ahaiev ${ }^{1, *}$, Dmytro Prytula ${ }^{1}$, Eduard Kliuiev ${ }^{1}$, Dmytro Zhytlonok ${ }^{2}$, Edgar Cabana $^{3}$, \\ and Liudmyla Kabakova ${ }^{1}$ \\ ${ }^{1}$ Institute of Geotechnical Mechanics named by N. Poljakov of National Academy of Sciences of \\ Ukraine, 49005, Dnipro, Simferopolska Str., 2a, Ukraine \\ ${ }^{2}$ State Enterprise "Toretskvuhillia", 85200, Toretsk, Druzhby Str., 19, Ukraine \\ ${ }^{3}$ Universidad Nacional de San Agustin de Arequipa, 04001, Arequipa, Calle Santa Catalina 117, Peru
}

\begin{abstract}
This article presents the results of the calculation of methane emission from the development of coal seam and enclosing rocks in the roof on Mine Management "Sukhodolska-Skhidna". The required degassing efficiency and the degassing method were determined. The degree of influence of mining -technical and mining-geological factors on the safety of the degassing system has established. The determination of the influence degree of mining factors on the safety of the degassing system can be used both at the design stage mine, mining and preparing it, which allow to predict and prevent the formation of an explosive concentration of methane-air mixture.
\end{abstract}

\section{Introduction}

It is known that in underground conditions the most important factors, which influencing on the safety of gas production in the coal mining, are methane concentration, flow rate and emission sources. The gas factor is the main reason, limiting the productivity of working areas. The presence of a "gas barrier" in mines with high gas content and difficulties, connected with it, reduce the efficiency of coal mining technology. Earlier in the coal industry, the main attention was paid to improving the technology and techniques of coal mining, and issues of gas control were given a secondary role. Nowadays, the main task is to increase the mining safety operations and the associated extraction of mine methane [1].

According to [2], $42 \%$ of DTEK's mines use degassing. Nine mines of them are classified as super-category (methane emissions over $15 \mathrm{~m}^{3} /$ ton or with blower gas emissions) and 7 mines are assigned to category 3 (methane emissions is $10-15 \mathrm{~m}^{3} /$ ton).

Thus, the purpose of the work is to estimate the influence degree of mining-geological and mining-technical factors on the safety of the degassing system, especially during designing mines [3] and predicting methane emissions.

To determine the factors, affecting on the safety of gas production in the coal mining [47], as an example, let's consider the conditions in 24th West sloping workface (24th WSW)

*Corresponding author: igtmdep16@gmail.com 
of the coal seam $i_{3}{ }^{1}$ at level $915 \mathrm{~m}$ of the Mine Management "Sukhodolska-Skhidna".

The exploitation of the 24th WSW with a regulatory capacity of 1250 ton per day is planned. The ventilation scheme of the workface is direct-flow with a cooling of the outgoing air stream. The direction of the air flow along the workface is upward.

The workface is equipped with a mechanized complex 3KD-90T, combine 2GSH-68B, conveyor SP-326. Shipment of rock mass from a mining site is carried out by belt conveyors $1 \mathrm{LT}-1000,1 \mathrm{~L}-1000 \mathrm{UD}$, through which coal is transported to a central coal bunker and delivered by skips on the surface.

The enclosing rocks of the immediate roof are composed of siltstone, sometimes overlaid with sandstone with a thickness of 1-4 $\mathrm{m}$. The main roof is represented by sandstone with a thickness up to $25.2 \mathrm{~m}$. The direct and main soil is represented by siltstone with a thickness up to $15 \mathrm{~m}$. The sandstones of the roof and coal seam $i_{3}{ }^{1}$ are outburst and gas-bearing. In accordance with the forecast of the sudden breakthrough of methane from the soil, the $24 \mathrm{WSW}$ is not dangerous.

Sources of methane emission in the mining working are the worked coal seam, the neighboring coal seams (satellites) and containing rocks. In conditions of the 24th WSW gas emission sources are:

- the thickness of worked coal seam $i_{3}{ }^{1}$ up to $1.7-2.5 \mathrm{~m}$;

- sandstone, lying in the roof of the seam $i_{3}{ }^{1}$ thickness up to $25.15 \mathrm{~m}$.

\section{Methods}

The calculation of the expected methane abundance of 24th WSW by methane emission sources was made in accordance with the guide on coal mine ventilation design [8]. The methane emission from the worked coal seam and enclosing rocks in the roof and the necessary degassing coefficient were calculated. The influence of degree of factors, when they increase on the degassing coefficient, as well as the determination of the influence percentage of each factor were obtained by using the statistical methods of results processing.

\subsection{Methane emission from the worked seam}

The calculation of methane emission from the worked seam $q_{s}\left(\mathrm{~m}^{3} /\right.$ ton $)$ was made according to the formula [8]

$$
q_{s}=q_{w m}+q_{c m}+k_{o l}\left(x-x_{o}\right)
$$

where $q_{w m}$ - relative methane emission from the workface of development coals, $\mathrm{m}^{3} /$ ton; $q_{c m}$ - relative methane release from extracted coal, $\mathrm{m}^{3} / \mathrm{ton} ; k_{o l}=0$ - the coefficient of the operational loss of coal within the mining site (it was not calculated because of the absence of operational losses); $x$ - the natural methane content of the seam, $\mathrm{m}^{3} / \mathrm{ton} ; x_{o}$ - the residual methane content of coal which remains in the worked-out area, $\mathrm{m}^{3} /$ ton.

$$
q_{w m}=0.85 \cdot x \cdot k_{m s} \cdot \exp (-n),
$$

where $k_{m s}$ - the influence of the mining system coefficient on the methane emission from coal seam; $n$ - the parameter, which depends on the rate of the working face advancement, the release of volatile substances from coal and the depth development.

$$
k_{m s}=\frac{L_{w}-2 b_{w y}}{L_{w}},
$$


where $L_{w}=345 \mathrm{~m}-$ the workface length; $b_{w y}=14 \mathrm{~m}-$ the coefficient, depending on the release of volatile substances [8];

$$
x=x_{g} \cdot k_{W A a},
$$

where $x_{g}=22.5 \mathrm{~m}^{3} /$ ton of dry ashless mass- the natural methane content of the seam,

$$
k_{W A a}=\frac{100-W-A_{a}}{100}
$$

where $k_{W A a}$ - the coefficient of methane content recalculation on coal seam; $W=3 \%$ - the coal seam humidity; $A_{a}=28.9 \%$ - the coal ash content,

$$
n=a_{1} \cdot V_{\mathrm{w}} \cdot \exp \left(-0.001 \cdot H+b_{1} \cdot V^{d a f}\right)
$$

where $a_{1}=0.152, b_{1}=0.051-$ empirical coefficients [8]; $H=1000 \mathrm{~m}-$ seam depth; $V_{w}=1.26 \mathrm{~m} /$ day - workface movement speed; $V^{d a f}=26.3 \%$ - the yield of volatile substances.

$$
q_{c m}=q_{m w}^{\prime}+q_{m c}^{\prime \prime}
$$

where $q_{m w}^{\prime}$ - relative methane release from coal extracted workface, $\mathrm{m}^{3} /$ ton; $q^{\prime \prime}{ }_{m c}$ - relative methane release from coal extracted in a belt entry, $\mathrm{m}^{3} / \mathrm{ton}$.

$$
\begin{gathered}
q_{m w}^{\prime}=x \cdot k_{m s}[1-0.85 \cdot \exp (-n)] \cdot\left(b_{2} \cdot k_{m b}+b_{3} \cdot k_{m w}^{\prime}\right), \\
q_{m c}^{\prime \prime}=x \cdot k_{m s}[1-0.85 \cdot \exp (-n)] \cdot b_{2} \cdot k_{c}^{\prime \prime}
\end{gathered}
$$

where $b_{2}=0.6, b_{3}=0.4$-empirical coefficients, which take into consideration the proportion of repulsed coal respectively on the conveyor and left on the soil in the workface at one-side coal extraction scheme [8]; $k_{m b}, k_{m w}^{\prime}, k^{\prime \prime}{ }_{c}-$ coefficients, which take into consideration the degassing degree of repulsed coal in the stope entry on the conveyor, on the soil in the workface and on the conveyor in the mining site:

$$
\begin{gathered}
k_{m b}=a \cdot T_{w}^{b}, \\
k_{m w}^{\prime}=a \cdot T_{c}^{b}, \\
k_{c}^{\prime \prime}=a \cdot T_{c}^{b}-a \cdot T_{w}^{b},
\end{gathered}
$$

where $T_{w}$ - the spending time of repulsed coal on the conveyor in the workface, min; $a=0.118, b=0.25$ - empirical coefficients, which characterizing gas recovery from repulsed coal [8],

$$
T_{w}=\frac{l_{w}}{60 \cdot V_{c}},
$$

where $V_{c}=1 \mathrm{~m} / \mathrm{s}$ - coal transportation speed in workface. 


$$
T_{\mathrm{c}}=\frac{\sum_{i=1}^{n_{i}} l_{m i}}{60 \cdot V_{m i}}
$$

where $T_{c}$ - the spending time of repulsed coal on the conveyor entry within the mining site, $\min ; n_{i}=2-$ the number of mining sections $l_{m i}$ at different speeds of coal; $l_{m i}=1000 \mathrm{~m}-$ the length of working with conveyor (SP-250 - $100 \mathrm{~m} ; 1 \mathrm{LT} 1000-900 \mathrm{~m}) ; V_{m i}=1.6 \mathrm{~m} / \mathrm{s}-$ coal transportation speed on the conveyor belt 1LT1000.

\subsection{Methane emission from enclosing rocks in the roof}

In accordance with the geological and forecasting passport of the mining site of 24th WSW the gas-bearing sandstones are deposited in the roof of the worked seam.

The calculation of methane emission from enclosing rocks in the roof $q_{\mathrm{p}}\left(\mathrm{m}^{3} /\right.$ ton) was made according to the formula [8],

$$
q_{p}=1.14 \cdot V_{w}^{-0.4}\left(x-x_{0}\right) \cdot k_{r}\left(H_{1}-H_{0}\right),
$$

where $k_{r}=0.00106$ - the empirical coefficient, taking into consideration the influence of the method of roof control and the lithological composition of rocks [8]; $H_{1}=1150 \mathrm{~m}-$ the depth development; $H_{0}=150 \mathrm{~m}$ - the depth of the upper boundary of the methane gas zone; $x_{0}$ - residual methane content of coal, left in the worked-out area in pillars and nonremovable packs, $\mathrm{m}^{3} /$ ton

$$
x_{0}=x_{r m} \cdot k_{W A a}
$$

where $x_{r m}=2.6 \mathrm{~m}^{3} /$ ton of dry ashless mass - the residual methane content of coal.

\subsection{Calculation of the required efficiency of degassing}

Let's determine the required degassing efficiency

$$
K_{d} \geq \frac{I_{c}-I_{a}}{I_{c}} \cdot 100, \%
$$

where $I_{c}$ - average expected methane release on the mining site, $\mathrm{m}^{3} / \mathrm{min} ; I_{a}$ - average methane rate, which can be diluted with air to a safe level, $\mathrm{m}^{3} / \mathrm{min}$.

$$
I_{a}=0.0078 \cdot Q_{c}
$$

where $Q_{c}$ - air flow rate for airing the mining site, $\mathrm{m}^{3} / \mathrm{min}$.

The maximum coefficient of advance degassing without fluid fracturing $k_{d s}$ is equal 0.2 [9]. In order to achieve the required degassing efficiency of 24th WSW its calculation is supposed to be carried out according to the formula

$$
K_{d} \leq\left(k_{d s}+\left(1-k_{o s}\right) \cdot\left(d_{r} \cdot k_{d r}+d_{s} \cdot k_{s}\right)+k_{o s}\left(d_{r}+d_{s}\right)\right) \cdot 100,
$$

where $k_{o s}, k_{d r}, k_{s}$ - the efficiency coefficients of the degassing of the worked-out area, roof and soil, fraction of units; $d_{r}, d_{s}=0$ - the percentage of methane emissions from the roof and soil in the total gas balance of this area.

Thus, the technological process of gas extraction from the coal deposits development is 
based on abidance of the safety conditions of miners, located in the mining site.

\section{Results and discussion}

The results of the influence of mining-geological and mining-technical factors on the safety of gas extraction in the coal mine are described in Table 1. For the convenience of calculations, the values of all parameters increased by $5 \%$, and the results were entered in Table 1, while their effect on safety conditions was recorded using computer simulation.

Table 1. The values of the increased dates of the mining -technical and mining-geological factors.

\begin{tabular}{|c|c|c|c|c|c|c|c|}
\hline \multirow{2}{*}{$\begin{array}{c}\text { Factor } \\
\text { number }\end{array}$} & \multirow{2}{*}{ Factor } & \multirow{2}{*}{ Value } & \multicolumn{5}{|c|}{ Increased dates } \\
\cline { 4 - 8 } & & $5 \%$ & $10 \%$ & $15 \%$ & $20 \%$ & $25 \%$ \\
\hline 1 & $L_{w}$ & 345.00 & 362.25 & 379.5 & 396.75 & 414.00 & 431.25 \\
\hline 2 & $l_{m i}$ & 1000 & 1050 & 1100 & 1150 & 1200 & 1250 \\
\hline 3 & $V_{m i}$ & 1.60 & 1.68 & 1.76 & 1.84 & 1.92 & 2.00 \\
\hline 4 & $T_{w}$ & 240 & 252 & 264 & 276 & 288 & 300 \\
\hline 5 & $k_{o l}$ & 0 & 0.05 & 0.10 & 0.15 & 0.20 & 0.25 \\
\hline 6 & $V_{c}$ & 1.00 & 1.05 & 1.10 & 1.15 & 1.20 & 1.25 \\
\hline 7 & $H_{0}$ & 150.0 & 157.5 & 165.0 & 172.5 & 180.0 & 187.5 \\
\hline 8 & $Q_{c}$ & 2907.00 & 3052.35 & 3197.70 & 3343.05 & 3488.40 & 3633.75 \\
\hline 9 & $x_{r m}$ & 2.60 & 2.73 & 2.86 & 2.99 & 3.12 & 3.25 \\
\hline 10 & $H_{1}$ & 1150.0 & 1207.5 & 1265.00 & 1322.50 & 1380.00 & 1437.50 \\
\hline 11 & $x_{g}$ & 22.50 & 23.625 & 24.75 & 25.88 & 27.00 & 28.13 \\
\hline 12 & $W$ & 3.00 & 3.15 & 3.30 & 3.45 & 3.60 & 3.75 \\
\hline 13 & $A_{a}$ & 28.9 & 30.345 & 31.79 & 33.24 & 34.68 & 36.13 \\
\hline 14 & $H$ & 1000 & 1050 & 1100 & 1150 & 1200 & 1250 \\
\hline 15 & $V_{w}$ & 1.260 & 1.323 & 1.386 & 1.450 & 1.512 & 1.580 \\
\hline
\end{tabular}

A graph of the change of the degassing coefficient from the values of mining-geological and mining-technical factors was showed in Figure 1.

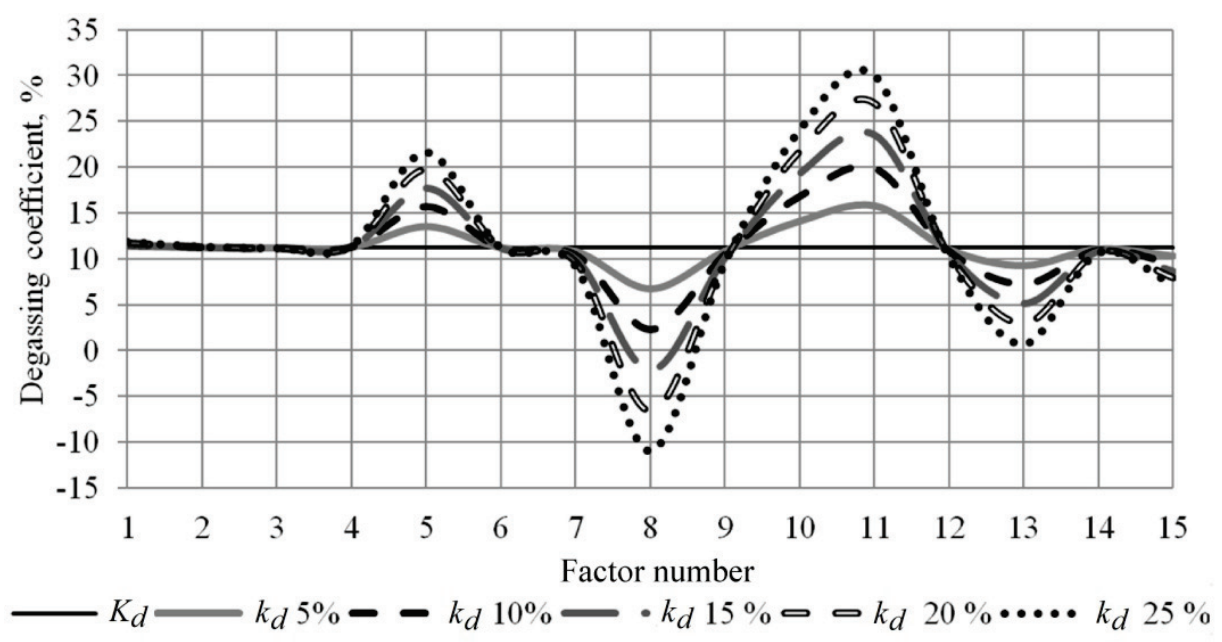

Fig 1. The change of the degassing coefficient from increasing values of mine factors.

According to Figure 1, the degassing factor changes with an increase of the following mine factors: $k_{o l}$ (factor 5), $Q_{c}$ (factor 8), $H_{1}$ (factor 10), $x_{g}$ (factor 11), $A_{a}$ (factor 13), $V_{w}$ 
(factor 15). An increase of other factors does not change the degassing coefficient significantly. Therefore, below we will consider only these six factors.

In the tables below the results of calculation of the degassing rate with an increase in mine values by the corresponding percentage (Table 2) and in recalculation by $1 \%$ (Table 3) were presented.

Table 2. The calculation results of the degassing coefficient with an increase of mining -technical and mining-geological factors by the corresponding percentage.

\begin{tabular}{|c|c|c|c|c|c|c|}
\hline \multirow{2}{*}{$\begin{array}{l}\text { Factor } \\
\text { number }\end{array}$} & \multirow[t]{2}{*}{ Factor } & \multicolumn{5}{|c|}{$\begin{array}{c}\text { Degassing coefficient increased value } k_{d} \\
\left(K_{d}=11.2167 \% \text { by an initial degassing coefficient }\right)\end{array}$} \\
\hline & & $5 \%$ & $10 \%$ & $15 \%$ & $20 \%$ & $25 \%$ \\
\hline 5 & $k_{o l}$ & 13.5114 & 15.6905 & 17.7624 & 19.7349 & 21.6151 \\
\hline 8 & $Q_{c}$ & 6.7776 & 2.3384 & -2.1007 & -6.5399 & -10.9791 \\
\hline 10 & $H_{1}$ & 14.1041 & 16.8095 & 19.3497 & 21.7394 & 23.9915 \\
\hline 11 & $x_{g}$ & 15.7509 & 19.8445 & 23.5587 & 26.9439 & 30.0421 \\
\hline 13 & $\overrightarrow{A_{a}}$ & 9.2920 & 7.2820 & 5.1809 & 2.9823 & 0.6794 \\
\hline 15 & $V_{w}$ & 10.3300 & 9.4900 & 8.6900 & 7.9500 & 7.2300 \\
\hline
\end{tabular}

With an increase of mine factors by $5 \%$ (such as $k_{o l}$ (factor 5), $H_{l}$ (factor 10), $x_{g}$ (factor $11)$ ), the degassing coefficient rises accordingly by $20 \%, 25.7 \%, 40.4 \%$ and with an increase by $5 \%$ (such as $Q_{c}$ (factor 8), $A_{a}$ (factor 13), $V_{w}$ (factor 15)) degassing coefficient decreases accordingly by $39.6 \%, 17.2 \%, 7.9 \%$. The change of the degassing coefficient from the mine factors occurs by linear dependence (Table 2).

Table 3. The calculation results of the degassing coefficient change with increasing mining- technical and mining-geological factors in recalculation by $1 \%$.

\begin{tabular}{|c|c|c|c|c|c|c|}
\hline \multirow{2}{*}{$\begin{array}{l}\text { Factor } \\
\text { number }\end{array}$} & \multirow[t]{2}{*}{ Factor } & \multicolumn{5}{|c|}{$\begin{array}{l}\text { The share of change in the degassing coefficient with an increase in } \\
\text { the factor values in recalculation by } 1 \%, S\end{array}$} \\
\hline & & $5 \%$ & $10 \%$ & $15 \%$ & $20 \%$ & $25 \%$ \\
\hline 5 & $k_{o l}$ & 2.7023 & 1.5690 & 1.1842 & 0.9867 & 0.8646 \\
\hline 8 & $Q_{c}$ & 1.3555 & 0.2338 & -0.1400 & -0.3270 & -0.4392 \\
\hline 10 & $H_{1}$ & 2.8208 & 1.6809 & 1.2900 & 1.0870 & 0.9597 \\
\hline 11 & $x_{g}$ & 3.1502 & 1.9845 & 1.5706 & 1.3472 & 1.2017 \\
\hline 13 & $\overrightarrow{A_{a}}$ & 1.8584 & 0.7282 & 0.3454 & 0.1491 & 0.0272 \\
\hline 15 & $V_{w}$ & 2.0664 & 0.9495 & 0.5801 & 0.3974 & 0.2893 \\
\hline
\end{tabular}

The change of the degassing coefficient with an increase of the factor value in recalculation by $1 \%$ was showed in Figure 2 .

As a result of calculated data analysis the approximation equation (Figure 2) in the form of degree functions and two degree polynomial was obtained by means of mathematical statistics methods, which can represented as:

$$
\begin{gathered}
S=0.3144 \cdot k_{o l}^{-0.71}, R^{2}=0.99 \\
S=0.5123 \cdot x_{g}^{-0.6}, R^{2}=0.99 \\
S=0.3683 \cdot H_{1}^{-0.672}, R^{2}=0.99 \\
S=0.056 \cdot V_{w}^{-1.215}, R^{2}=0.99
\end{gathered}
$$




$$
\begin{aligned}
& S=62.945 \cdot A_{a}{ }^{2}-27.366 \cdot A_{a}+2.9957, R^{2}=0.98 \\
& S=63.027 \cdot Q_{c}{ }^{2}-27.209 \cdot Q_{c}+2.4847, R^{2}=0.98 .
\end{aligned}
$$

where $R^{2}$ - approximation accuracy.

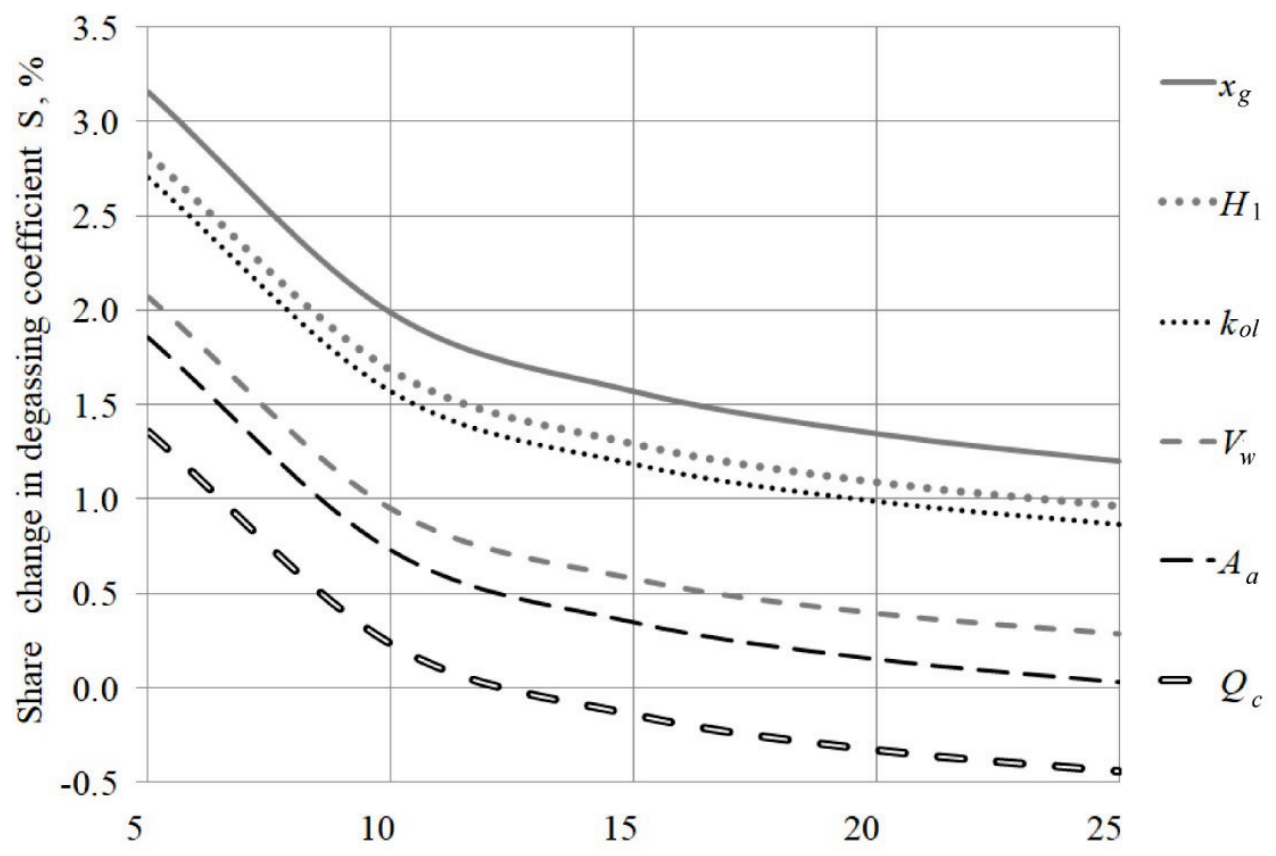

Degassing coefficient $k_{d}, \%$

Fig. 2. The change of the degassing coefficient with increasing mine factors in recalculation by $1 \%$.

\section{Conclusion}

The influence degree of mining-geological and mining-technical on the change of the degassing coefficient was determined. Among the mining factors that have the greatest degree of influence on the safety of the degassing system in the mining coal are: the coefficient of the operational loss of coal within the mining site $k_{o l}$; air flow rate for airing the mining site $Q_{c}$; workface movement speed $V_{w}$. Among the mining-geological factors that have the greatest influence on the safety of gas production the mining coal are: the depth development $H_{1}$; the natural methane content of the seam $x_{g}$; the ash content of coal $A_{a}$

The change of degassing coefficient with an increase of mining-technical and mininggeological factors on $1 \%$ occurs by a two-degree polynomial and degree functions with approximation accuracy $R^{2}=0.98-0.99$.

These results can be used both at the design stage mine, mining and preparing it, which allow to predict and prevent the formation of an explosive concentration of methane-air mixture. 


\section{References}

1. Ahaiev, R., Vlasenko, V., Dudlia, K., Kyrychenko, M., Prytula, D. (2017). On the possibility of coalbed methane extraction as a source of energy under the hydrodynamic impact on the outburst coal seam. Advanced Engineering Forum Submitted, 25, 106-112

2. Shushov, M. (2018) Preliminary degassing of coal seams as a factor in improving safety and labor productivity. In: Dnipro II International Conference on Coal Industry. Retrived from https://dtek.com/content/files/maksim-shishov.pdf

3. R. Dychkovskyi, V. Falshtynskyi, V. Ruskykh, E. Cabana, O. Kosobokov. A modern vision of simulation modelling in mining and near mining activity. E3S Web of Conferences, Ukrainian School of Mining Engineering, 60 (2018). https://doi.org/10.1051/e3sconf/20186000014

4. V. Vlasenko, V. Gavrilov, O. Moskovskiy. Influence of hydrodynamic impact on degassing of steep coal seam at the top of the overhead longwall (CRC Press/Balkema: EN Leiden, The Netherlands, 2015)

5. E. Cabana, V. Falshtynskyi, P. Saik, V. Lozynskyi, R. Dychkovskyi. A concept to use energy of air flows of technogenic area of mining enterprises. E3S Web of Conferences, Ukrainian School of Mining Engineering, 60 (2018). https://doi.org/10.1051/ e3sconf $/ 20186000004$

6. R. Dychkovskyi, O. Vladyko, D. Maltsev, E. Cabana. Some aspects of the compatibility of mineral mining technologies. Rudarsko Geolosko Naftni Zbornik, 33 (2018). https://doi.org/10.17794/rgn.2018.4.7

7. V. Vlasenko, D. Zhytlonok. Hydrodynamic impact on coal mass before crossing the most outburst-prone coal seams. E3S Web of Conferences, International Conference Essays of Mining Science and Practice, 109 (2019). https://doi.org/10.1051/e3sconf/201910900112

8. DNPAOP 1.1.30-6.09 (1994) Kerivnytstvo z proektuvannia ventylyatsiyi vuhilnykh shakht. Kyiv: Ministerstvo palyva ta enerhetyky Ukrainy

9. SOU 10.1.00174088.001 (2004) Kerivnytstvo po proektuvanniu dehazatsii vuhilnykh shakht. Pravyla bezpechnoi ekspluatatsii dehazatsiinykh system. Kyiv: Minpalenerho Ukrainy 